2. Ластовский А.А., Комаров А.М. Памятники с микролитическим инвентарем низовьев реки Малый Узень // Археологические культуры Северного Прикаспия: межвуз. сб. науч. тр. Куйбышев: Куйбышевск. пед. ин-т, 1988. С. 42-51.

3. Иванов И.В., Васильев И.Б. Человек, природа и почвы рын-песков Волго-Уральского междуречья в голоцене. М.: Интеллект, 1995. 264 с.

4. Археология Нижнего Поволжья. В 4 т. Каменный век / под общ. ред. д-ра ист. наук А.С. Скрипкина. Волгоград: Волгоградское научное издательство, 2006. Т. 1.458 с.

5. Артюхова О.А., Бексеитов Г.Т., Першикова Т.Н. Полевые исследования палеолитического отряда УКАЭ в 2003 году // Вопросы истории и археологии
Западного Казахстана: сб. научных статей. Вып. 2. Уральск, 2003. С. 51-63.

6. Артюхова О.А., Мамиров Т.Б., Бирмуханова О.А., Майгельдинов К.У. Отчет о полевых исследованиях Ешкитауского отряда в 2005 году. Алматы, 2006. Рукопись. Фонды Института археологии им. А.Х. Маргулана. № 2715, Опись 2. 149 с.

7. Васильев И.Б., Выборнов А.А., Комаров А.А. Мезолитические памятники Северного Прикаспия // Археологические культуры Северного Прикаспия: межвуз. сб. науч. тр. Куйбышев: Куйбышевск. пед. ин-т, 1988. С. 42-51.

Статья публикуется при поддержкке гранта 1824/ГФ4 МОН РК «Древнейшее население АралоКаспийского региона: миграции и эволюции культур (эпохи камня и палеометалла)».

\title{
MESOLITHIC MONUMENT NOVAYA KAZANKA 1 IN THE NORTHERN CASPIAN REGION
} (MATERIALS OF 2005)

\section{(C) 2017}

Artukhova Olga Anatoljevna, candidate of historical sciences, leading researcher of Prehistoric Department A.Kh. Margulan Institute of Archaeology (Almaty, Republic of Kazakhstan)

Mamirov Talgat Basarbaevich, candidate of historical sciences, leading researcher of Prehistoric Department; head of Archaeological Heritage Department

A.Kh. Margulan Institute of Archaeology (Almaty, Republic of Kazakhstan); National Museum of Republic of Kazakhstan (Astana, Republic of Kazakhstan) Klyshev Yerlan Yersainovich, postgraduate student of the Chair of World History Kalmyk State University named after B.B. Gorodovikov (Elista, Russian Federation)

\footnotetext{
Abstract. This paper provides information about exploring of the Stone Age at the site Novaya Kazanka 1 in sand dunes on the western shore of Lake Soraidyn by employees of Institute of Archeology named after A.Kh. Margulan. They worked on the monument in 2003 and 2005. 8 accumulations of stone artifacts were allocated on the monument. The pits laid at the site showed the absence of the buried cultural layer. Stone artifacts were made mainly of two types of raw materials - siliceous rock and quartzite sandstone. The typological description of the stone collection of accumulations at the Novaya Kazanka 1 site indicates their chronological diversity ranging from purely Mesolithic complexes to mixed Meso-Neolithic ones. The technique of primary splitting is represented by unit nuclei and fragments of small dimensions. The tools are represented by scrapers, mostly end-plates on fragments of plates, lamellar flakes, plates and fragments of retouched plates, geometric microliths (segments, trapeziums, and triangles) and others. The stone inventory of the accumulations at the Novaya Kazanka 1 site does not contradict the conclusions about the correlation of the monuments near Lake Soraidyn with the monuments of the «Istai group» of the Seroglazov culture, which is expressed both in raw materials preferences and in the technique of primary splitting, as well as in the collection of stone implements.

Keywords: stone age; Mesolithic; Neolithic; Seroglazov culture; artifacts; stone tools; siliceous rock; quartzite sandstone; Holocene; cultural layer; geometric microliths; scrapers; plates; nucleuses; retouch; sand dunes; Lake Soraidyn; village of Novaya Kazanka; Northern Caspian.
}

\section{DECORATION OF BONE AND ANTLER ARTEFACTS AS AN INDICATION OF MESOLITHIC NETWORKS (FINDS FROM A CENTRAL SWEDISH LATE MESOLITHIC SITE)}

\author{
Larsson Lars, professor of Archaeology and Ancient History Department \\ Lund University (Lund, Kingdom of Sweden) \\ Molin Fredrik, researcher \\ National Historical Museum (Linköping, Kingdom of Sweden)
}

Abstract. Our knowledge of Mesolithic decorated bone and antler tools from Scandinavia has mainly been based
on finds from sites and single finds from Southern Scandinavia. However, recent excavations at a Late Mesolithic
site at Strandvägen in Motala, south-central Sweden, have changed the state of research and revealed a large number
of bone and antler tools, some of them with decorations. The site is located on the eastern shore of Lake Vättern, the
second largest lake in the south of Sweden and at the only large outlet of the lake. The site was used during a number
of centuries, with a concentration of radiocarbon dates around 7500-7000 cal. BP. The settlement at Strandvägen is
the only site in this part of Scandinavia with a large number of finds of bone and antler. The location of the site was 
exceptional as it was easily available by contact links to the south and north as well as east and west. This is well manifested in the find material. Leister points are the single largest group of tools, with a total of more than 400 examples. A number of these are furnished with decoration in the form of small notches on the barbs more or less in systematic order, as well as cross-hatched motifs. A small number of other tools such as slotted daggers and antler objects with shaft holes are also decorated. In comparison with southern Sweden and Denmark, similarities are obvious concerning both the choice of motifs and the variety of their execution. The only other area in the Baltic region with a number of decorated objects is the East Baltic. However the chronological relevance is uncertain. For example one can find leister points with similarities to the finds at Strandvägen among the finds from Lake Lubāna in southeastern Latvia. The question of how many of the motifs, and how they are executed is a pan-Mesolithic phenomenon within Northern Europe and how much can be related to specific regional markings.

Keywords: Late Mesolithic; South-Central Sweden; Strandvägen in Motala; ornamented bone and antler objects; prehistoric contact links; leister points; cultural parallels with Eastern Baltic; pan-Mesolithic phenomenon within Northern Europe; regional peculiarities.

\section{Introduction}

Our knowledge of Mesolithic ornamented bone and antler tools from Scandinavia has mainly been based on finds from sites and single finds from Southern Scandinavia. However, recent excavations at the Late Mesolithic site of Strandvägen in Motala, south-central Sweden, have changed the state of research and revealed a large number of bone and antler tools, some of them with ornamentation.

The site is located on the north-eastern shore of Lake Vättern, the second largest lake in the south of Sweden, at the only outlet of the lake to the Baltic Sea, which at the time of settlement was located about $30 \mathrm{~km}$ to the east (fig. 1).

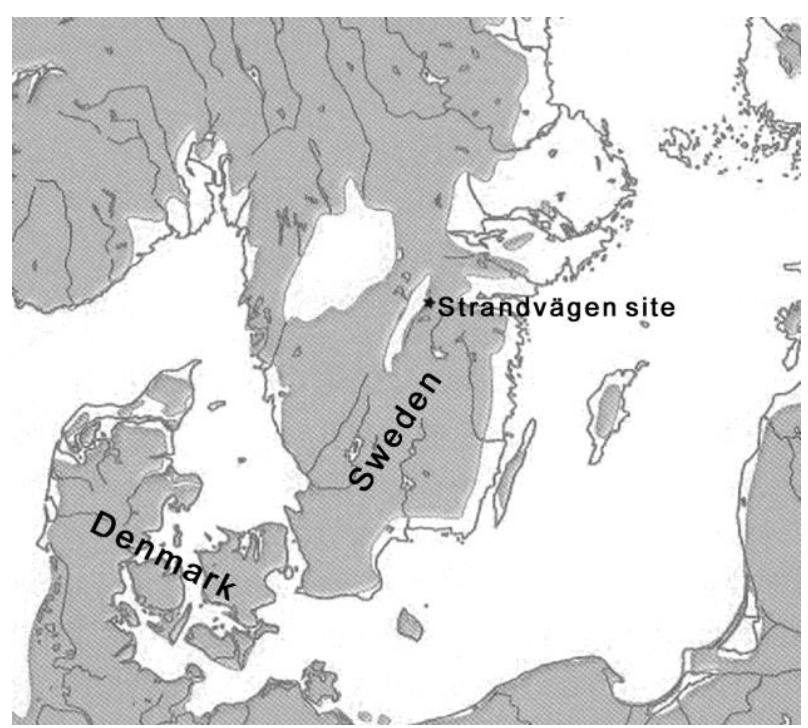

Figure 1 - The location of the Strandvägen site

Vättern as a lake was isolated from the Yoldia Sea at about 10,800 cal. BP with a first outlet to the north. However, due to changes as a result of greater land uplift in the north than the south, areas were flooded along the southern part of the lake and areas in the north were exposed. Through these changes, the main outlet - the river Motala Ström - was first formed at 9200 cal. BP, resulting in the lowering of Lake Vättern by a couple of metres, and then lowered yet again and stabilized at $c .7800$ cal. BP. After these drastic events there seems to have been an unaltered relationship between land and water for many generations - an area where the world in one important aspect stood still. For a considerable part of the Late Mesolithic the water level beside the site seems to have been the same as it is today. The last Mesolithic remains on the site are dated $c .6500 \mathrm{cal}$. BP [1;2].

The site was excavated in different stages due to a change in the railway system $[1 ; 2]$. A considerable part of the site has been excavated, including the refuse area below the present shoreline, the lower slope of a ridge, with extensive settlement remains in the form of several houses and knapping floors for lithics, and the top of the ridge, with a Mesolithic cemetery [3] (fig. 1). Only a section of the higher part of the site and probably the lower part of the cemetery was not accessible for excavation.

Such an extensive excavation of various parts of a site, with the remains of different activity areas, is exceptional within Scandinavia. The site was used for several centuries, with a concentration of radiocarbon dates at 7500-7000 cal. BP [2].

Most of the bone and antler tools were found in the refuse area of the settlement. As the present shoreline is the same as in the prehistoric situation, by enclosing part of the area beyond the present shore and pumping away the water, it was possible to uncover a large number of organic finds on the bottom [4]. The settlement at Strandvägen is the only site in the central part of Scandinavia with a large number of finds of bone and antler, due to the absence of layers with suitable preservation conditions in the region.

\section{Networks}

When considering networks, one has to look for factors that might create a demand for contacts as well as sites that provide focal points for the distribution of raw material and objects, in addition to which one must seek information about manufacturing and use, which relate to function as well as to integration into a social and mental sphere.

The location of the site was exceptional, as it was easily accessible through links to the south and north as well as to the east and west [1].

The combination of ecological conditions that existed at the outflow of Motala Ström was exceptional, and resource utilization provided a basis for greater population density than in other parts of eastern Sweden. This must have meant that the concentration of inhabitants, and probably also settlements, was much greater here than in other parts of eastern Sweden. It is highly probable that special social structures occurred at the outflow of Motala Ström, compared to other parts of the region. It is also possible to use the term «central place» - as for other periods of prehistory - in the sense of social constellations, structures and activities that are exceptional. A bigger and denser social unit requires clearer rules for the participants' interaction, which can be reflected in expressions of a symbolic nature and in traces of rituals - in the former case taking the form of ornamented objects, and in the latter the form of votive deposits and graves. A central place also functions as a hub of centripetal and centrifugal network patterns. Centripetal re- 
fers both to the accumulation of raw material, especially materials of an exotic nature, and to a function as a focal point for the inhabitants of the region, a place where they met on certain occasions [5]. As a centrifugal effect, objects which required time-consuming labour or a high level of technical skill were produced at the central place and then distributed from it.

The composition of the lithic material testifies to an extensive network of contacts. Before the excavation the area around the site was perceived as a transitional zone between the flint-based settlement area to the south and the quartz-based area to the north [6]. In the analysis of the Strandvägen site, parallels have been drawn with areas such as the western part of Sweden, with Cambrian flint from Kinnekulle a distance of roughly $95 \mathrm{~km}$ to the west [7], and with the Stockholm region, some $180 \mathrm{~km}$ to the north-east, since tools of slate known from this region have been found at Strandvägen [1]. The sources of Cretaceous flint from Southern Scandinavia are located at least $350 \mathrm{~km}$ away in Scania, the southernmost part of Sweden or flint transported by the ice along the Swedish west coast.

As regards the Strandvägen site, a cemetery with several graves, a number of houses and fishing platforms constructed just off the shore indicate that the place was used for permanent operations, as is also suggested by the occurrence of lithic finds, which are unusually copious for the region. The composition of the lithic material testifies to an extensive network of contacts.

\section{Ornamented bone and antler objects}

Our special interest has been focused on the ornamented objects made of bone and antler. Here, the term «ornamentation» covers all intentional carvings that have no relation to the manufacturing and use of the object. It includes a variety of carvings, from a few lines to complicated motifs. The find material has been intensively examined, and even the smallest fragments of ornamented objects have been identified. It is the only major corpus of material, as far as we know, that has been so well scrutinized. Very few objects are intact, most being in a very fragmentary state.

Together with other aspects, the intensity of ornamentation might be accepted as one factor that could be related to a site of special function, such as a central site. Altogether, 75 finds are ornamented. Because of the fragmentary condition of the material there are a number of uncertain aspects. One is how many objects they belong to. Based upon the size of the fragments, they could very well belong to a small number of objects. The largest number of ornamented pieces within one and the same group is 35, and these belong to leister points and harpoons. Most of these fragments are rather large, with at least two or three barbs. Had they appeared in smaller fragments, as the ornaments are so similar, they could have been interpreted as belonging to a much smaller number of tools.

\section{Leister points and harpoons}

Leister points and harpoons constitute the single largest group of tools, with a total of 460 examples, almost all in a fragmentary state. Thirty-five of these have some kind of ornamentation, most commonly cuts on the barbs. They can be divided in two groups based on the manner of execution. In some cases there is a marked notch in the barb, although two notches have also been recorded (fig. 2: 4). On some larger leister point fragments, all the surviving barbs have been incised, but ex- amples with notches on every second barb also appear Another ornament consists of finer cuts on barbs with broad frontal parts. In most cases they appear in pairs or at intervals along both edges of the barb (fig. 2: 5-6). This kind of ornament appears on a couple of barbs of harpoons as well. In a few instances cuts have been identified on the basal part of a harpoon.

Yet another type of ornament on leister points is a motif on the edge opposite the barbed side. A small number have small cuts like the ones described above on the opposite edge to the barbs. Others have zigzag engravings, cross-hatching or groups of transverse lines (fig. 3: 6-9).

Ornaments on leister points and harpoons are rare in Scandinavia. A couple of finds with zigzag engravings are known on Danish leister points probably dating from the early part of the Mesolithic [8]. Among later single finds, such as a number of points from a bog in central Scania, there are no ornamented pieces [9]. Just a couple of finds from about the same age as Strandvägen have certain parallels in Southern Scandinavia. One is a harpoon from Grave IV at Skateholm II in southern Scania. The barbs are cross-hatched and with fine cuts on both sides of the barb [10, p. 138]. Another find, from the Bredasten site in southern Scania, has fine cuts on both sides of the barb [11, fig. 10: $b$ ].

Although there are few single finds of tools of bone or antler from eastern and northern Sweden, there are some with ornamentation. A find from Stora Djulö, Södermanland, was decorated with angled bands and accumulations of lines of varying orientation at the base of the object [8, fig. 58: 1] indicating that this kind of ornament might have been more common in central Sweden than in southern Scandinavia.

There is considerable variation between different regions of Scandinavia in terms of the amount of material available for comparison. Just a small number of bone and antler objects have been found in central and northern Sweden. Ornamented objects are even fewer in number. Only one object, the blade of a slotted bone dagger from northern Sweden, is ornamented [12]. However, this seems to be an exotic object from Southern Scandinavia. Just a small number of ornamented pieces have been found in western Sweden [13]. In Norway a couple of cave sites have yielded bone material and objects, but the number of ornamented objects, even including stone tools with shaft holes, is rather limited [14]. Just one find, an ornamented reindeer antler, originates from Finland [15].

\section{Eastern contacts}

In the Baltic and western Russia ornamented leister points and harpoons do appear, mainly as single finds. One such area is Lake Lubāna in south-eastern Latvia. Small cuts and lines on the barbs are known, as are notches in the barbs [16, fig. IV: 1-2, fig. XIX: 4, fig. XXII: 1-5]. The problem is that none of these finds have been radiocarbon-dated. Most can be included in the Kunda type, belonging to the Early Mesolithic, of which only a few have been dated and shown to belong to the Early Mesolithic [9]. Leister points with similar ornaments are known from other sites in western Russia $[17 ; 18]$. Despite the problems of dating, it seems that ornamented leister points and harpoons were a more common phenomenon in the eastern part of Northern Europe.

Another form, represented by a couple of finds, consists of flat points, probably fragments of spearheads, shaped with a narrow shoulder cut into the side of the 
Larsson L., Molin F.

Decoration of bone and antler artefacts as an indication of Mesolithic...

07.00.00 - исторические науки и археология

edges. The edges have additionally been given notches. This form has certain similarities to the leister points and harpoons described above. Here we see objects that have been cut to a shape whose function, whether as decoration or of practical significance, must be described as uncertain. This form also has distinct parallels in the Baltic area [16].

Indications of contacts with the Baltic area can be supplemented with some other objects from Strandvägen which have no ornamentation. Arrowheads with bone tangs with a clear triangular cross-section which occur among the finds are a well-attested form in the Baltic
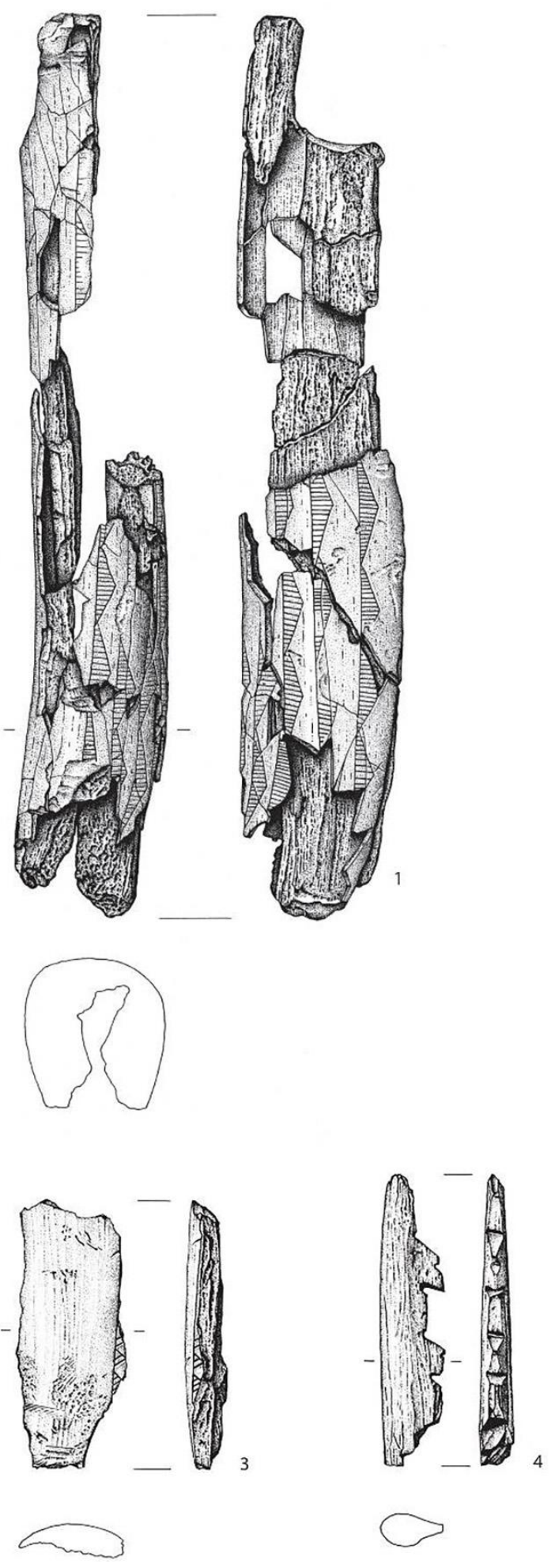

Figure 2 - Ornamented objects from Strandvägen, Motala.
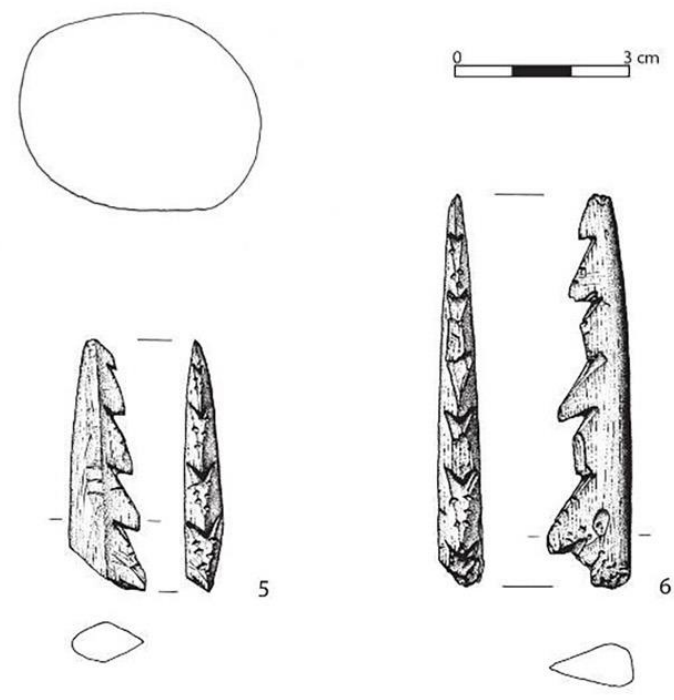

1-2- ornamented antler object broken in the shaft-hole; 3-fragment of ornamented object; 4- leister point with notches on barbs; 5-6-leister points with small notches on the front of the barbs. Drawings by Björn Wallebom 

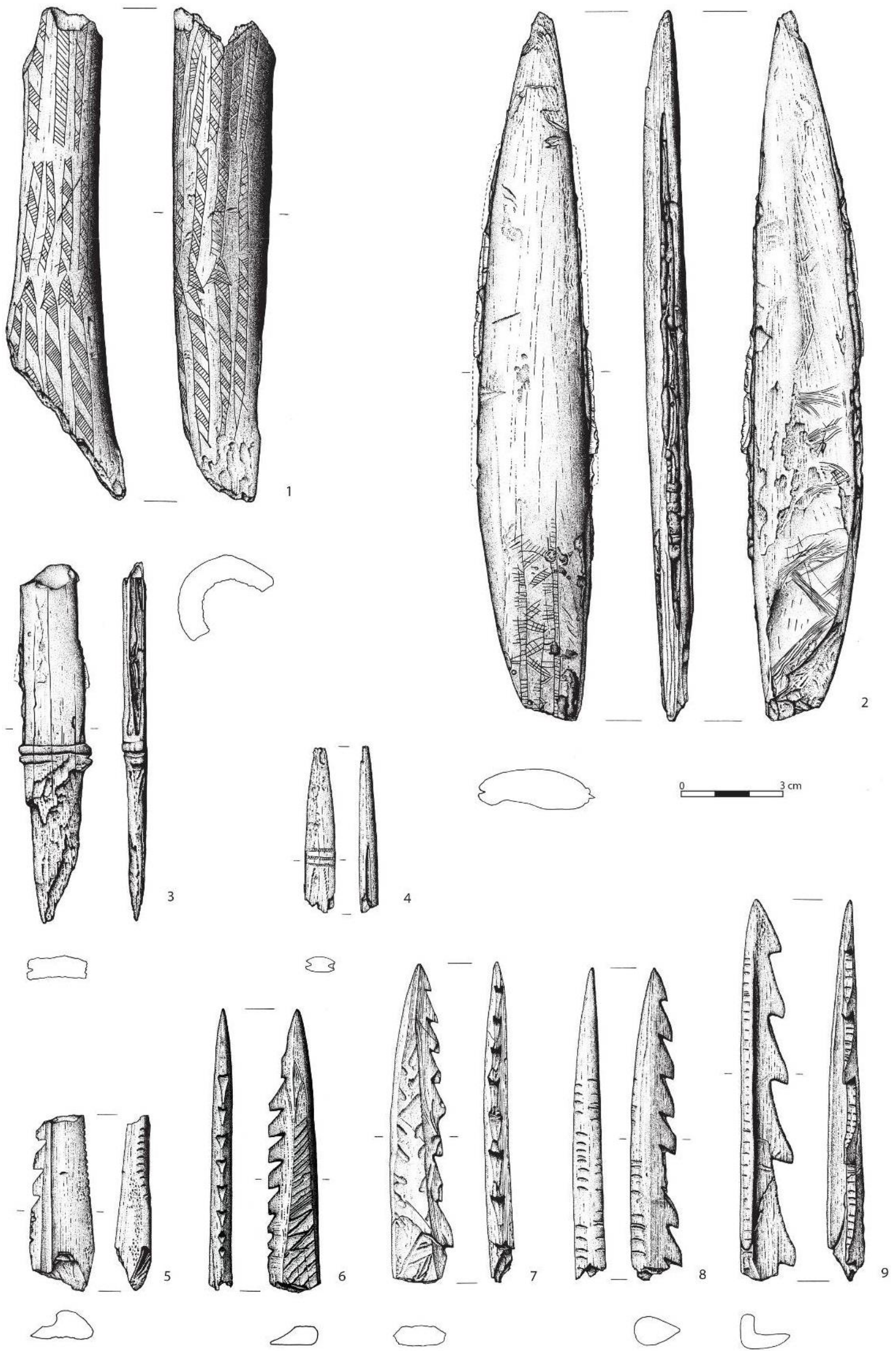

Figure 3 - Ornamented objects from Strandvägen, Motala. 1 - fragment of an ornamented antler object; 2 - slotted dagger; 3 -fragments of slotted dagger; 4- point of a slotted dagger; $5-9$ - leister points with ornaments on the side and opposite side of the barbs. Drawings by Björn Wallebom

\section{Southern contats}

Most of the different kinds of tools found at Strandvägen are well known in southern Sweden and Denmark from settlement sites as well as single finds $[21 ; 8]$. One group with several examples consists of objects made of antler with a shaft hole [8]. Some might have been used as axes or adzes, even as handles [22], but several have a shape that makes the practical function most uncertain. A considerable number of these objects are ornamented. Three certain examples and one uncertain piece, on which the shaft hole has not been identified, have been found at Strandvägen, and all are 
ornamented. One has simple ornaments, while three have motifs that cover larger parts of the surface (fig. 2: 2-3). The ornaments can be compared to well-known motifs, such as rows of hatched triangles and parallel bands on examples from Southern Scandinavia [21; 8]. Yet another fragment of antler totally covered with ornamentation might be part of a similar tool (fig. 3: 1). These objects with shaft holes and ornamentation do not occur in the Baltic lands.

Another tool usually provided with ornamentation is the slotted bone dagger (fig. 3: 2-4). At least three examples have been found at Strandvägen. The blade is fully preserved on one of these, with ornamentation on both sides (fig. 3: 2). As on slotted daggers from Southern Scandinavia, the ornaments are more regular on the upper, somewhat concave side of the blade [5;12]. In this case the slots in the dagger are fitted with microblades made of mylonitic quartz - recrystallized quartz with flint-like qualities. Although there are slotted bone points in Baltic finds, there are no daggers of the form that occurs in Southern Scandinavia [23; 12].

\section{Conclusions}

Because of the absence of sites with good preservation we do not know whether the bone and antler tools from Strandvägen indicate a special relationship to southern Scandinavia as well as to the Baltic during the Late Mesolithic. This was also based upon long-lived contact with a pan-Mesolithic relation to the ornamentation, or else it is an example of contacts with the east during the Early Mesolithic, as is evidenced in the stone technology [7]. In our opinion, the latter possibility is the most reasonable.

\section{REFERENCES:}

1. Carlsson T. Where the river bends. Under the boughs of trees. Strandvägen - a Late Mesolithic settlement in Eastern Middle Sweden. Acta Archaeologica Lundensia, Series in 80, No 55. Riksantikvarieämbetet, Stockholm, 2008.

2. Molin F., Gruber G., Hagberg L. Motala - a North European Focal Point?. F. Riede \& M. Tallaavaara (eds.), Lateglacial and Postglacial Pioneers in Northern Europe, BAR International Series 2599. Archaeopress, Oxford, 2014. P. 91-102.

3. Gummesson S., Molin F. The Mesolithic cemetery at Strandvägen, Motala, in eastern central Sweden // Mesolithic burials - Rites, symbols and social organisation of early postglacial communities. International Conference Halla (Saale), Germany, 18th-21st September 2013 / J. Grünberg, B. Gramsch, L. Larsson Orschietd, H. Meller (eds.). Landesmuseum für Vorgeschichte, Halle, 2016. P. 145-159.

4. Gummesson S., Molin F. Points of Bone and Antler from the Late Mesolithic settlement in Motala, eastern central Sweden // D. Groß, H. Lübke, J. Meadows, D. Jantzen (Eds.) (in prep.), Working at the sharp end: from bone and antler to Early Mesolithic life in Northern Europe. Untersuchungen und Materialien in SchleswigHolstein und im Ostseeraum 10.

5. Larsson L. From blank spot to focal point. An eastern Swedish site from a south Scandinavian perspective // G. Gruber (ed.), Identities in transition. Mesolithic Strategies in the Swedish province of Östergötland. Riksantikvarieämbetet, Arkeologiska undersökningar skrifter 46, Stockholm, 2005. P. 24-35.
6. Welinder S. The Pre-Pottery Stone Age of Eastern Middle Sweden. Antikvariskt arkiv 48. Kungl. Vitterhets, Historie, och Antikvitetsakademien, Stockholm, 1973.

7. Knutsson H., Knutsson K., Molin F., Zetterlund P. From flint to quartz: Organization of lithic technology in relation to raw material availability during the pioneer process of Scandinavia. Quaternary International 424, 2015. P. 32-57.

8. Plonka T. The Portable Art of Mesolithic Europe. Wroclaw, 2003.

9. Larsson L., Nilsson Stutz L., Zagorska I., Bērziņš V., Ceriņa A. New aspects of the MesolithicNeolithic cemeteries and settlement at Zvejnieki, northern Latvia.

10. Larsson L. Ett fångstsamhälle för 7000 år sedan. Boplatser och gravar vid Skateholm. Lund, 1988.

11. Larsson M. Bredasten - An Early Ertebølle Site with a Dwelling Structure in South Scania. Papers of the Archaeological Institute University of Lund 1985-1986, 1988. P. 25-49.

12. Larsson L. Regional or interregional? A slotted bone dagger from Offerdal, Jämtland // R. Engelmark, T.B. Larsson, L. Rathje (eds.), en lång historia... Festskrift till Evert Baudou på 80-årsdagen. Archaeology and Environment 19. Umeå. 2005.

13. Nordqvist B. Västkusten, Larsson M., Olsson E. Regionalt och Interregionalt. Stenåldersundersökningar i Sydoch Mellansverige. Arkeologiska undersökningar Skrifter 23, Riksantikvarieämbetet, Stockholm, 1997. P. 32-46.

14. Bergsvik K.A., David É. Crafting Bone Tools in Mesolithic Norway: A Regional Eastern-Related KnowHow. European Journal of Archaeology. 2014. P. 1-32.

15. Mannermaa K. An ornamented antler artefact (C. 6200 cal BC) from southern Finland and its northern European context. Mesolithic Miscellany 24:2. 2016. P. 19-30.

16. Vankina L. The Collection of Stone Age Bone and Antler Artefacts from Lake Lubāna. Latvijjas Véstures Muzeja Raksti 4. Riga, 1999.

17. Zilin M.G. Das Mesolithicum im Gebiet zwischen den Flüssen Wolga und Oka: einige Forschungsergebinisse det letzen Jahre. Praehistorische Zeitschrift 81:1. 2006. P. 1-48.

18. Oshibkina S.V. Art from Mesolithic period based on materials from Veretje culture. Moscow, 2017.

19. Browall H. Mesolitiska mellanhavanden i västra Östergötland. A. Gustavsson \& H. Karlsson (eds.), Glyfer och arkeologiska rum - en vänbok till Jarl Nordbladh. Gotarc Series A, Vol. 3, Göteborg, 1999. P. 289303.

20. Apel J., Wallin P., Storå J., Possnert G. Early Holocene human population events on the island of Gotland in the Baltic Sea (9200-3800 cal. BP) [El. resource] // Quaternary International. 2017.

21. Nash G. Exchange, Status and Mobility. Mesolithic portable art of southern Scandinavia. BAR International Series 710. Oxford, 1998.

22. Broadbent N. Perforated Stones, Antlers and Stone Picks. Evidence for the Use of Digging Sticks in Scandinavia and Finland. Tor 1975-1977. 1978.

23. Indreko R. Die Mittlere Steinzeit in Estland. Kungl. Vitterhets, Historie och Antikvitets Akademiens Handlingar 66. Stockholm, 1948. 


\title{
ОРНАМЕНТАЦИЯ АРТЕФАКТОВ ИЗ КОСТИ И РОГА КАК ИНДИКАТОР СИСТЕМ КОММУНИКАЦИЙ В МЕЗОЛИТЕ (ПО НАХОДКАМ С ПАМЯТНИКА ПОЗДНЕГО МЕЗОЛИТА В ЦЕНТРАЛЬНОЙ ШВЕЦИИ)
} (C) 2017

\author{
Ларссон Ларс, профессор кафедры археологии и древней истории \\ Лундский университет (г. Лунд, Королевство Швеция) \\ Молин Фредерик, научный сотрудник \\ Национальный исторический музей (г. Линчёпинг, Королевство Швеция)
}

Аннотащия. Наши знания о скандинавских орнаментированных изделиях из кости и рога по большей части основывались на случайных находках и находках с поселений из Южной Скандинавии. Однако недавние раскопки позднемезолитического памятника Страндваген в Мотале (южная-центральная Швеция) изменили состояние исследований и позволили получить большое количество костяных и роговых изделий, некоторые из которых орнаментированные.

Памятник расположен на восточном берегу оз. Ваттерн, второго по величине озера на юге Швеции, у единственной протоки из озера. Поселение функционировало на протяжении нескольких столетий, наибольшая концентрация радиоуглеродных датировок приходится на период 7500-7000 кал. л.н. Для этой части Скандинавии Страндваген является единственным памятником с большим числом находок из кости и рога.

Памятник выделяется своим расположением, обеспечивающим легкость контактов с территориями к северу и югу, а также к западу и востоку. Это хорошо проявляется в коллекции находок.

Наконечники острог составляют единственную крупную группу орудий, всего более 400 единиц. Значительное число этих предметов украшено орнаментом в виде насечек и зубцов, расположенных более или менее симметрично, также представлены мотивы с пересекающейся штриховкой. Орнамент присутствует и на небольшом числе других изделий, таких как вкладышевые кинжалы и роговые муфты.

Очевидно сходство с изделиями из южной Швеции и Дании в отношении выбора мотивов и вариаций их нанесения.

Единственным балтийским регионом с большим числом находок орнаментированных изделий является Восточная Прибалтика. Однако хронологическое соотношение этих материалов неясно. К примеру, наконечники острог, схожие с найденными в Страндвагене, обнаруживаются среди материалов Лубанской низины в юго-восточной Латвии.

Обсуждаются вопросы о том, насколько представленные мотивы и способы их исполнения являются общемезолитическим североевропейским феноменом и насколько они могут быть связаны со специфическими региональными отличительными признаками.

Ключевые слова: поздний мезолит; Южная-Центральная Швеция; Страндваген в Мотала; орнаментированные предметы из кости и рога; доисторические системы коммуникаций; наконечники острог; культурные параллели с Восточной Балтикой; общемезолитический североевропейский феномен; региональные особенности.

УДК 902/904

Статья поступила в редакцию 14.04.2017

\section{КЕРАМИКА РАННЕГО НЕОЛИТА ОТ СРЕДНЕЙ АЗИИ ДО ДАНИИ}

(C) 2017

Андреев Константин Михайлович, кандидат исторических наук, доцент кафедры отечественной истории и археологии

Выборнов Александр Алексеевич, доктор исторических наук, профессор, заведующий кафедрой отечественной истории и археологии

Самарский государственный социально-педагогический университет (2. Самара, Российская Федерация)

Аннотащия. Статья посвящена анализу керамики культур раннего неолита на обширной территории от Приаралья на востоке до Дании на западе. Выделяются наиболее устойчивые типологические и технологические признаки древнейшей посуды: профилированность верхней части сосудов, остродонность, слабая орнаментированность, узоры нанесены ямками под срезом венчика или прочерками, композиции представлены пересекающимися линиями типа косой решетки. Сосуды изготовлены из илистой глины с примесью шамота. Поверхности фрагментов заглажены мягким предметом. Эта совокупность признаков прослеживается для керамики культур Приаралья, лесостепного Поволжья, Подонья и Поднепровья, вплоть до Ютландии. Радиоуглеродные даты для культур раннего неолита интересуемой территории свидетельствуют о достаточно древнем возрасте в восточной части ареала (6200 лет ВС) и достаточно плавном переходе до более молодых (5900 лет ВC) в западной зоне. Прослеживается совмещенный хроноинтервал памятников елшанской культуры и эртебелле. Причиной восточного тренда появления наиболее ранней керамики к западу от Приаралья могли явиться климатические катаклизмы (аридизация), а механизмами появления ранней керамики на западе стали хозяйственно-бытовые компоненты.

Ключевые слова: ранний неолит; культура; технология изготовления керамики; керамическая традиция; Средняя Азия; лесостепное Поволжье; Среднее Подонье; Поднепровье; абсолютная хронология; присваивающее хозяйство; рыболовство; эртебелле. 